\title{
Evaluation Of Patients Visiting The Emergency Department With The Occlusion Of Central Venous Catheter Used For Hemodialysis
}

\author{
Hemodiyaliz İçin Kullanılan Santral Venöz Kateterin Tıkanıklığı İle Acil Servise Başvuran Hastaların \\ Değerlendirilmesi \\ Filiz Baloğlu Kaya ${ }^{1}$, Şeyhmus Kaya ${ }^{2}$, Engin Özakın ${ }^{1}$, Ahmet Tuğrul Zeytin ${ }^{3}$ \\ ${ }^{1}$ Eskisehir Osmangazi University, Faculty of Medicine, Department of Emergency Medicine, Eskişehir, Turkey \\ ${ }^{2}$ Eskisehir City Hospital, Department of Emergency Medicine, Eskişehir, Turkey \\ ${ }^{3}$ Bilecik Provincial Health Directorate, Bilecik, Turkey
}

\begin{abstract}
Introduction: In hemodialysis patients, the rate of central venous catheter (CVC) use as venous access device is $13-25 \%$. This application has complications such as catheter-related thrombosis. In CVC occlusion, anticoagulant and thrombolytic treatments are used to clear the obstruction. Catheter is also renewed when necessary. In this study, we aim to evaluate the catheter occlusion-related visits to emergency department (ED) in terms of patient and catheter characteristics and to investigate the applied treatments.

Methods: This retrospective study was conducted at an ED of a university hospital between 01.01.2015-31.12.2020. All patients over 17 years of age, who visited the ED with occlusion of CVC used for hemodialysis, were included in the study.

Results: 52 ED visits were included in the study. The mean age was 63.15 and $34(65.4 \%)$ were female. 33 of the CVC (63.5\%) were uncuffed. Right subclavian vein was the most frequently obstructed catheter location as seen in 14 visits (26.9\%). Catheter occlusion was seen in 0-1 year of catheter use at most (11 visits). In 17 visits (31\%) a drug (unfractionated heparin in 10, alteplase in 7) was used to clear the obstruction. No statistically significant difference was detected between two drugs in catheter patency. In 15 of all visits and 10 of those administered a drug, catheter clearance was successful in the ED. No statistically significant relationship of successful catheter patency with patients' additional diseases and laboratory tests was detected. In 30 of all patients $(57.7 \%)$, a CVC was placed because of the unsuccessful catheter clearance and the need for urgent dialysis.

Conclusion: It is important for emergency physicians to identify CVC occlusions and make appropriate interventions, especially in patients who require urgent dialysis. Unfractionated heparin and alteplase should be kept in mind by emergency physicians to reduce the need for catheter replacement.
\end{abstract}

Key words: Hemodialysis, catheter, thrombolytic

\section{ÖZET}

Giriş: Hemodiyaliz hastalarında venöz yol aracı olarak santral venöz kateter (SVK) kullanım oranı \%13-25'dir. Bu uygulamanın katetere bağlı tromboz gibi komplikasyonları vardır. SVK oklüzyonunda tıkanıklığı gidermek için antikoagülan ve trombolitik tedaviler kullanılır. Gerektiğinde kateter de yenilenir. Bu çalışmada, kateter tıkanıklığı ile ilgili acil servise (AS) yapılan başvuruları, hasta ve kateter özellikleri açısından değerlendirmeyi ve uygulanan tedavileri araştırmayı amaçladık.

Yöntemler: Bu retrospektif çalışma 01.01.2015-31.12.2020 tarihleri arasında bir üniversite hastanesinin acil servisinde yapılmıştır. Hemodiyaliz için kullanılan SVK tıkanıklığı ile acil servise başvuran 17 yaş üstü tüm hastalar çalışmaya dahil edilmiştir.

Bulgular: Çalışmaya 52 acil servis başvurusu dahil edildi. Olguların yaş ortalaması 63.15 olup 34'ü (\%65.4) kadındı. SVK'nın 33'ü (\%63.5) kafsızdı. Sağ subklavian ven 14 başvuruda (\%26.9) en sık tıkanan kateter yeriydi. Kateter tıkanıklığı en fazla 0-1 yıllık kateter kullanımında (11 başvuru) görüldü. Başvuruların 17 'sinde (\%31) tıkanıklığı gidermek için bir ilaç (10'da fraksiyone olmayan heparin, 7'de alteplaz) kullanıldı. Kateter açıklığı sağlamada iki ilaç arasında istatistiksel olarak anlamlı fark saptanmadı. Tüm başvuruların 15'inde ve ilaç uygulananların 10'unda, acil serviste kateter açıklığı başarılı şekilde sağlandı. Başarılı kateter açıklığı ile hastaların ek hastalıkları ve laboratuvar testleri arasında istatistiksel olarak anlamlı bir ilişki saptanmadı. Tüm hastaların 30'unda (\%57.7) kateter açıklığının başarısız olması ve acil diyaliz intiyacı nedeniyle SVK yerleştirildi.

Sonuç: Acil hekimlerinin özellikle acil diyalize intiyacı olan hastalarda SVK tıkanıklıklarını tespit etmeleri ve uygun müdahaleleri yapmaları önemlidir. Kateter değiştirme intiyacını azaltmak için acil hekimleri tarafından fraksiyone olmayan heparin ve alteplaz akılda tutulmalıdır.

Anahtar Kelimeler: Hemodiyaliz, kateter, trombolitik

Corresponding author: Filiz Baloğlu Kaya, Eskisehir Osmangazi University, Faculty of Medicine, Department of Emergency Medicine, Eskişehir, Turkey E-mail: fbaloglu@ogu.edu.tr Eskisehir Med. J. 2021; 2(3):172-177.

Received date:19.08.2021 Accepted date:27.10.2021

Authors: Filiz Baloğlu Kaya (ORCID: 0000-0001-6197-0682), Şeyhmus Kaya (ORCID: 0000-0002-8701-6675), Engin Özakın (ORCID: 0000-0003-43015440), Ahmet Tuğrul Zeytin (ORCID: 000-0002-1420-5475) 


\section{INTRODUCTION}

Placement of central venous catheters (CVC) is one of the necessary initiatives in renal replacement therapy for patients with end-stage renal disease. In hemodialysis patients, arteriovenous fistulas are the first line intervention, as well as the rate of CVC use as venous access device is $13-25 \%(1,2)$. This frequently used application has complications such as catheterrelated thrombosis, which can lead to catheter malfunction to life threatening conditions such as pulmonary embolism.

It is important to detect the loss of catheter function in the early period in patients who present to the emergency department (ED) with a clinical condition that requires dialysis, and to perform the necessary applications to eliminate the problem. In this way, both the catheter is protected and morbidity arising from the clinical situation that requires CVC can be prevented.

The aim of this study was to evaluate the ED admissions due to CVC occlusion used for hemodialysis in terms of patient and catheter characteristics and to investigate the applied treatments and their results.

\section{METHODS}

This retrospective study was conducted at the Emergency Department of Eskisehir Osmangazi Health, Practice and Research Hospital in 6 years (01.01.2015-31.12.2020). The study was approved by the ethics committee (25.05.2021/08).

All patients over 17 years of age, who visited the emergency department with occlusion of CVC used for hemodialysis, were included in the study. Catheter infections, kinging of the catheter, tight sturation and pressure of the catheter against the vessel wall were accepted as exclusion criteria. Patient demographic data, additional diseases, type of hemodialysis catheter, catheter insertion time, catheter location, clotting-related laboratory values, cause of occlusion, method used to clear catheter occlusion, response to this method, and patient emergency service outcome were all evaluated. The data of the cases were obtained from the patient registry system.

\section{Statistical Analysis}

The categorical data were indicated as frequency and percentage (\%). The continuous variables were indicated as the means and standard deviation. Shapiro-Wilk test was used to evaluate data conformity to normal distribution. Chi-Square analysis was used in the analysis of the cross tables created. IBM SPSS Statistics 21.0 (IBM Corp. Released 2012. IBM SPSS Statistics for Windows, Version 21.0. Armonk, NY: IBM Corp.) was used for analysis. A $p$ value $<0.05$ was considered statistically significant.

\section{RESULTS}

During the study period, it was observed that 510268 patients over the age of 17 were admitted to the ED. A catheter dysfunction was detected in 52 of the 61 applications that had catheter occlusion-related complaints. The mean age of the cases included in the study was $63.15 \pm 14.57$ (38 to 91 ) and 34 (65.4\%) cases were female. 9 patients had more than one visit with the same condition.

33 of the central venous catheters (63.5\%) were uncuffed. The duration of catheter use was determined as $0-1$ years with $11(21.2 \%)$ admissions most commonly. However, in $61.5 \%$ of the visits, the duration of catheter use was not recorded. We detected that right subclavian vein was the most frequently obstructed catheter location as seen in 14 visits (26.9\%). However, in $25.0 \%$ of the visits, the catheter location was not recorded. Catheter characteristics are given in Table 1.

In 33 visits (64.3\%), normal saline was inserted in to the catheter and in 17 visits (31\%) a drug (unfractionated heparin in 10, alteplase in 7) was administered to clear 
Table 1. Central venous catheter (CVC) characteristics

\begin{tabular}{|c|c|}
\hline & $\mathbf{n}(\%)$ \\
\hline CVC type & $19(36.5)$ \\
Uncuffed & $33(63.5)$ \\
\hline Duration of CVC use & \\
$0-1$ years & $11(21.2)$ \\
$0-5$ years & $6(11.5)$ \\
$>5$ years & $3(5.8)$ \\
Unknown & $32(61.5)$ \\
\hline Catheter location & $14(26.9)$ \\
Right subclavian vein & $9(17.3)$ \\
Right femoral vein & $5(9.6)$ \\
Left subclavian vein & $5(9.6)$ \\
Right internal jugular vein & $4(7.7)$ \\
Left femoral vein & $2(3.8)$ \\
Left internal jugular vein & $13(25.0)$ \\
Unknown &
\end{tabular}

the obstruction. In 5 of those who used normal saline and 10 of the patients administered a drug, catheter clearance was successful in the ED. Drug administration was seen to be more successful than normal saline administration to achieve catheter clearance $(p=0,003)$. In 5 of 10 patients administered unfractionated heparin and in 5 of 7 patients administered alteplase, the clearance was successful. However, no statistically significant difference was detected between two drugs in catheter clearance $(\mathrm{p}=0.622)$ (Table 2).

No statistically significant relationship of successful catheter clearance with patients' additional diseases (diabetes mellitus, hypertension, coagulation disorders, heart failure), laboratory tests (hemoglobin, platelet, APTT, INR) and CVC type were detected ( $p>0.05$ for all parameters) (Table 3 ).

Table 2. Efficacy of treatment in providing central venous catheter (CVC) clearance

\begin{tabular}{|l|c|c|c|}
\hline \multirow{2}{*}{ Treatment } & \multicolumn{2}{|c|}{$\begin{array}{c}\text { CVC Clearance } \\
\text { (n) }\end{array}$} & p \\
\cline { 2 - 3 } & $(-)$ & $(+)$ & \\
\hline Application & 28 & 5 & \multirow{2}{*}{0.003} \\
$\quad$ Salin Flush & 7 & 10 & \\
$\quad$ Drug & 5 & 5 & 0.622 \\
\hline Drug & 2 & 5 & \\
Anticoagulation (UFH) & 5 & \\
Thrombolytic (Alteplase) & 2 & \\
\hline
\end{tabular}

Abb. UFH; unfractionated heparin

In 30 of all patients (57.7\%), CVC was replaced because of the unsuccessful catheter clearance and the need for urgent dialysis. We observed that right femoral vein was the most frequently preferred location to place a new catheter by the emergency physicians (in 13 visits-25.0\%). Twenty five (48.1\%) of the cases included in the study were discharged from the ED and, in 18 of all visits (34.6\%), the patients were hospitalized from the ED. It was found that $9(17.3 \%)$ of the cases left the ED of their own free will.

\section{DISCUSSION}

Providing the vascular path, which is urgently required for patients in need of hemodialysis, with CVC saves time until the preparation of the arteriovenous fistula or graft, which is the optimal vascular path. Some patients, on the other hand, continue to be treated with permanent or temporary CVCs because they are not anatomically or physically suitable for these surgical procedures. Although it shows regional changes worldwide, the prevalence of CVC use for hemodialysis is reported to be $2-49 \%$ (3). Along with these variable rates, some complications arising from patient or 
Table 3. The relationship between central venous catheter (CVC) clearence and patient characteristics

\begin{tabular}{|c|c|c|c|}
\hline \multirow[t]{2}{*}{ Patient Caracteristics } & \multicolumn{2}{|c|}{ CVC Clearance (n) } & \multirow[b]{2}{*}{$\mathbf{P}$} \\
\hline & $(-)$ & $(+)$ & \\
\hline Diyabetes Mellitus (+) & 14 & 4 & 0.523 \\
\hline Hypertansion (+) & 18 & 7 & 1.000 \\
\hline Heart Failure (+) & 2 & 3 & 0.152 \\
\hline Coagulation disorders (-) & 34 & 15 & 1.000 \\
\hline Hemoglobin $<7$ g/dL & 10 & 4 & 1.000 \\
\hline Platelet $<150.000 / \mu \mathrm{L}$ & 4 & 2 & 1.000 \\
\hline INR $>1.1$ & 18 & 9 & 0.348 \\
\hline aPTT> 40 seconds & 21 & 10 & 0.494 \\
\hline Uncuffed cathether & 22 & 9 & 1.000 \\
\hline
\end{tabular}

catheter characteristics are encountered during the use of CVCs. Obstructions occur after infections, which are the most common complication. The mechanism of the obstruction on the CVC may be mechanical (kinking of the catheter, tight suture, catheter pushed against the vessel wall) or thrombotic (internal intraluminal thrombosis or external thrombosis, catheter-associated thrombus, or a fibrin sheath).

When looking at thrombotic-induced CVC obstructions in the ED, there were no clear data about the patient's age in the literature. However, the mean age of our patient group was $63.15 \pm 14.57$ and the age range (3891 years) was found to be quite wide. When looking at CVC-induced thrombosis with gender, no definitive information could be found in the literature. However, in the US Renal Data System data, it has been stated that the use of CVC for hemodialysis is more preferred in women than in men. (4). Since it is used more frequently, more complications can be expected in women. Women constituted $65.4 \%$ of the study group as well.

CVC occlusion has been shown to be the cause of recurrent cases as subclavian vein use, hypercoagulable states, and multiple access trials that cause endothelial damage during application (5). In the study group, 9 patients with recurrent admissions did not have a history of intervention in the records, but the most common CVC site was found to be the right femoral vein. Catheter usage period was determined as 0-1 year most frequently. No pathological finding was found in the examinations related to coagulation.

There are also some catheter-related risk factors for thrombosis in CVC. One of these risk factors is that the catheter is uncuffed (5). $63.5 \%$ of CVCs in the study group were uncuffed (Table 1). Dysfunctions that develop after CVC application are called early catheter dysfunction if they occur in less than 2 weeks, and late catheter dysfunction if they occur later. Although the underlying cause is technical problems such as catheter type malposition or kinking in the early period, thrombotic events are often the cause in the late period (6). It has been reported that CVCs have failed of 50$91 \%$ due to mechanical reasons within the first year after application $(7,8)$. In $61 \%$ of the study group, data on catheter duration was not found, but when the registered ones were examined, it was determined that occlusion occurred most frequently in the first year $(21.2 \%)$ (Table 1). Subclavian vein has been reported to be at high risk in terms of CVC location in thrombotic events (5). In $61.5 \%$ of the study group, no record was found about the location of the relevant catheter. However, considering the registered ones, it was seen 
that the occlusion was in the subclavian vein at a rate of 26.9\% (Table 1).

Early detection of catheter dysfunction was essential to prevent permanent access loss, inadequate dialysis and further morbidity. When CVC dysfunction occurs, mechanical causes should be primarily checked. If the catheter is not malpositioned and is thought to be a thrombotic condition, the first recommended forceful saline flush (10 mL) is applied into the CVC (5). This is a procedure that is applied frequently and is often stated as effective. However, in the study group, only in 5 of 33 patients administered normal saline, the clearance was successful.

Data regarding the success and outcome of systemic anticoagulation use in isolated CVC thrombi is limited. In partial CVC occlusion, especially if there are alternative vascular acces, anticoagulant drug administration is recommended in appropriate patients (5). Intravenous unfractionated unfractionated heparin at a bolus of 60- 70 units $/ \mathrm{kg}$ (approximately 5,000 units). This is followed by a continuous infusion at 12 15 units $/ \mathrm{kg} / \mathrm{hr}$ (approximately 1,000/hr) targeting an activated partial thromboplastic time of 1.5-2.5. In patients with low embolization risk, the catheter can be removed simultaneously with the initiation of anticoagulation, but CVC removal is recommended 3-5 days after the initiation of anticoagulation in risky patients (9). It was added that in case of large ( $>1.5$ $\mathrm{cm})$ thrombus, this treatment should continue for 6 months or until thrombus disappears before removing the caterer (9). In the study group, it was observed that CVC clearence was achieved in 5 out of 10 cases who were administered unfractionated heparin.

Recombinant tissue plasminogen activator (tPA) alteplase and other IPA derivatives were used for intraluminal thrombolysis in CVC occlusion, studies have shown that thrombolytic therapy is effective and safe for CVC patency (10). Although different regimens were used in studies, IPA was shown to be $1 \mathrm{mg}$ per lumen (single treatment) and an additional $1 \mathrm{mg}$ per lumen, as required, has shown a short-term success rates up to $83-98 \%$ (11). If CVC patency cannot be achieved with localized thrombolytic therapy, systemic 6-8 hour infusion is recommended. In the study group, it was observed that localized alteplase was applied to 7 cases and clearance was achieved in 5 of them. No study comparing anticoagulant and IPA applications was found in the literature. Although the number of cases was small in the study group, there was no difference in providing CVC clearence in patients who were given unfractionated heparin and alteplase. However, a significant difference was found when drug administration (unfractionated heparin and alteplase) was compared with normal saline $(p=0.003)$.

In CVC occlusion, catheter can be removed if there is an alternative central venous access or catheter infection, or when the treatment (anticoagulation or IPA) is contraindicated or unsuccessful (5). In the literature, we could not find data on catheter replacement rate and catheter location in this group of patients in the ED. In the study group, it was observed that a new catheter was inserted in $30(57.7 \%)$ cases, and the right femoral vein was preferred as the new catheter site by emergency physicians.

No clear data could be found in the literature regarding the emergency service outcome of patients admitted to the ED with CVC occlusion. The clinical conditions of these patients may require urgent hemodialysis or, on the contrary, be stable. In the study group, 25 (48.1\%) of the cases were discharged, $16(30.8 \%)$ were hospitalized in service beds and 2 in intensive care units.

The retrospective approach of our study might be regarded as a limitation. Lack of data in some cases (caterer location, duration, etc.) in the records affected the data of the study. 


\section{CONCLUSION}

It is essential for the emergency physicians to detect catheter dysfunction and to implement an appropriate treatment plan especially in patients who require urgent hemodialysis. When central venous catheter occlusion is caused by a thrombosis, the applications of unfractionated heparin and alteplase would decrease the rate of catheter renewal, especially in selected patients. This would also decrease complication risks related to further invasive procedures and delay in patients' dialysis treatments.

Conflict of Interest: The authors declare that they have no conflict of interest.

Financial Disclosure: This research did not receive any specific grant from funding agencies in the public, commercial, or not-for-profit sectors

\section{REFERENCES}

1. Lok CE. Fistula first initiative: advantages and pitfalls. Clin J Am Soc Nephrol. 2007;2:1043e53.

2. Ethier J, Mendelssohn DC, Elder SJ, et al. Vascular Access use and outcomes: an international perspective from the dialysis outcomes and practice patterns study. Nephrol Dial Transpl. 2008;23:3219e26.

3. Pisoni, RL, Zepel L, Port FK, Robinson BM. Trends in US vascular access use, patient preferences, and related practices: an update from the US DOPPS practice monitor with international comparisons. Am J Kidney Dis. 2015;65, 905-15.

4. Shah S, Leonard AC, Meganathan K, Christianson AL, Thakar CV. Gender and racial disparities in initial hemodialysis access and outcomes in incident end-stage renal disease patients. Am J Nephrol. 2018;48, 4-14.

5. Gunawansa N, Sudusinghe DH, Wijayaratne DR. Hemodialysis Catheter-Related Central Venous Thrombosis: Clinical Approach to Evaluation and Management. Ann Vasc Surg. 2018;51:298-305.

6. Niyyar VD, Chan MR. Interventional nephrology: Catheter dysfunction--prevention and troubleshooting. Clin J Am Soc Nephrol. 2013;8(7):1234-43.

7. Marr KA, Sexton DJ, Conlon PJ, Corey GR, Schwab SJ, Kirkland KB. Catheter-related bacteremia and outcome of attempted catheter salvage in patients undergoing hemodialysis. Ann Intern Med. 1997;127(4):275-80.

8. Hodges TC, Fillinger MF, Zwolak RM, Walsh DB, Bech F, Cronenwett $\mathrm{JL}$. Longitudinal comparison of dialysis access methods: risk factors for failure. J Vasc Surg. 1997;26(6):1009-19.

9. Wall C, Moore J, Thachil J. Catheter-related thrombosis: A practical approach. J Intensive Care Soc. 2016;17(2):160-7.

10. Brophy DF, Martin EJ, Gehr TW, Carr ME Jr. Enhanced anticoagulant activity of enoxaparin in patients with ESRD as measured by thrombin generation time. Am J Kidney Dis. 2004;44(2):270-7.

11. Clase CM, Crowther MA, Ingram AJ, et al. Thrombolysis for restoration of patency to hemodialysis central venous catheters: a systematic review. J Thromb Thrombolysis 2001;11:127-36. 